\title{
Managing sands of the Lower Mekong Basin to limit land degradation: a review of properties and limitations for crop and forage production
}

\author{
Richard Bell ${ }^{1}$, Vang Seng ${ }^{2}$, Wendy Vance ${ }^{1}$, Joshua Philp ${ }^{3}$, Sarith Hin ${ }^{4}$, Veasna Touch ${ }^{4}$, and \\ Matt Denton ${ }^{3}$ \\ ${ }^{1}$ Murdoch University \\ ${ }^{2}$ General Directorate of Agriculture \\ ${ }^{3}$ University of Adelaide School of Agriculture Food and Wine - Waite Campus \\ ${ }^{4}$ Cambodian Agricultural Research and Development Institute
}

January 20, 2021

\begin{abstract}
Land development is rapidly occurring on sand-dominant soils that cover substantial areas of the Lower Mekong Basin. Sands are at risk of degradation on sloping uplands where agriculture is expanding and on lowland landscapes where intensification of cropping is occurring. Sandstone and granitic geology explain the prevalence of sand-dominant texture in profiles. The sand terrains in uplands of Cambodia and southern Laos mostly have not been comprehensively mapped and their diversity and edaphic properties are poorly understood. On high permeability sands, lowland rainfed rice crops are drought-prone, while nutrient losses from leaching are also a risk. Furthermore, waterlogging, inundation and subsoil hardpans are significant water-related hazards that influence the choice of field crops and forages for lowland soils. Land use change in the lowlands to alternative field crops and forages on sands is contingent on their profitability relative to rice, the amounts and reliability of early wet season rainfall and amounts of stored water available after harvesting rice. Soil acidity, low nutrient status, hardsetting and shallow rooting depth are significant constraints for crops and forages on sands in the lowlands. Low soil fertility and soil acidity are limitations to the productivity of farming systems on the sand profiles in uplands, while erosion, low soil organic matter levels and water balance are concerns for their sustainable use. There is a need for widespread land suitability assessment and the development of sustainable farming systems before uncontrolled expansion of agriculture causes degradation of sandy terrain of the Lower Mekong Basin.
\end{abstract}

\section{Hosted file}

Sandy Soils of the Lower Mekong Basin 18 Dec 2020.pdf available at https://authorea.com/ users/390768/articles/504992-managing-sands-of-the-lower-mekong-basin-to-limit-landdegradation-a-review-of-properties-and-limitations-for-crop-and-forage-production 